\title{
WestVirginiaUniversity
}

THE RESEARCH REPOSITORY @ WVU

Graduate Theses, Dissertations, and Problem Reports

2019

\section{Stories of Deindustrialization: Exploring Narratives in Weirton, West Virginia}

\author{
Ella Jennings \\ ellakjennings18@gmail.com
}

Follow this and additional works at: https://researchrepository.wvu.edu/etd

\begin{abstract}
Recommended Citation
Jennings, Ella, "Stories of Deindustrialization: Exploring Narratives in Weirton, West Virginia" (2019).

Graduate Theses, Dissertations, and Problem Reports. 4036.

https://researchrepository.wvu.edu/etd/4036

This Problem/Project Report is protected by copyright and/or related rights. It has been brought to you by the The Research Repository @WVU with permission from the rights-holder(s). You are free to use this Problem/Project Report in any way that is permitted by the copyright and related rights legislation that applies to your use. For other uses you must obtain permission from the rights-holder(s) directly, unless additional rights are indicated by a Creative Commons license in the record and/ or on the work itself. This Problem/Project Report has been accepted for inclusion in WVU Graduate Theses, Dissertations, and Problem Reports collection by an authorized administrator of The Research Repository @ WVU. For more information, please contact researchrepository@mail.wvu.edu.
\end{abstract}




\section{WestVirginiaUniversity \\ THE RESEARCH REPOSITORY @ WVU}

Graduate Theses, Dissertations, and Problem Reports

2019

Stories of Deindustrialization: Exploring Narratives in Weirton, West Virginia

Ella Jennings 
"Stories of Deindustrialization:

Exploring Narratives in Weirton, West Virginia"

Ella Jennings

Professional project report submitted to the Reed College of Media at West Virginia University in partial fulfillment of the requirements for the degree of:

Master of Science in Journalism

\author{
Mary Kay McFarland, M.A., Chair \\ Glynis Board, M.A. \\ Emily Corio, M.A. \\ John Temple, M.F.A.
}

Journalism

Morgantown, West Virginia 2019

Keywords: Deindustrialization, steel industry, Weirton, West Virginia, podcast

Copyright 2019 Ella Jennings 


\section{Abstract \\ "Stories of Deindustrialization: \\ Exploring Narratives in Weirton, West Virginia"}

\section{Ella Jennings}

Since the 1960s, cities throughout the world have confronted the phenomenon of deindustrialization, wherein economies advance and transition into a post-industrial environment. This evolution leads to complications on political, social, and economic scales, as localities struggle to find a path to the future that can guarantee the job security and community identity once offered by industry. Weirton, West Virginia, is one such place. The city, once home to Weirton Steel Corporation, a powerhouse steelmaker that employed 13,000 people, fell victim to the fall of the United States' steel industry, and now is a shadow of its former self. This project showcases the struggles of Weirton in its post-industrial state by means of a five-part, personal narrative podcast. The episodes feature both voices of those who have worked in the mill as well as townspeople who were affected by the decline of the city to trace the history of the city and examine the social costs of deindustrialization. What was found were stories of suicide, population loss, economic hardships, as well as hopes for the future. 


\section{Acknowledgements}

This project would not have been possible without the talented, wise, and ever-encouraging support groups behind me, in both academic and social realms of my life.

First, I give my endless thanks to Professor Mary Kay McFarland for always offering her guidance and teaching me how to refine the difficult but rewarding art of storytelling.

Next, I offer my gratitude to Glynis Board for her willingness to take on the task of being my editor and lending her ear to my drafts as I worked on my presentation as a budding audio journalist.

My sincere thanks to both Professor Emily Corio and Professor John Temple for graciously accepting my request to sit on my committee and imparting invaluable journalism skills during their undergraduate classes that empowered me to reach where I am today.

I want to give thanks to Dr. Diana Martinelli for her outstanding graduate class that introduced me to the research methods that allowed me to successfully prepare my proposal.

I am also grateful for my advisors Tricia Petty and Dr. Steve Urbanski for pushing me towards the $4+1$ program and having their full faith in my ability to complete this degree.

And, I want to express my boundless appreciation for Jake, Justice, Mandi, Nick, and Darcie, my loving, creative, and encouraging friends who kept me sane during trying times and always offered a helping hand in anyway possible during this project. 


\section{Table of Contents}

Proposal

Introduction

Literature Review____ 2

Historical Background of Weirton __ 2

Deindustrialization and the Need for Narrative __ 5

Media Projects on Industrial Decline ___ 6

Research Statement __ 11

Methodology__ 12

Audience___ 16

Project Summary __ 16

Project Chronology __ 17

Discussion__ 26

Conclusion __ 31

Limitations and Suggestions for Future Research ___ 32

Appendix A _ 36

Appendix B _ 39

Bibliography ___ 40 


\section{Introduction}

On March 1, 2018, President Donald Trump announced his plan to impose a 25 percent tariff on steel imports and a 10 percent tariff on aluminum imports (Schlesinger, 2018). Staying in-line with his campaign promises, he defended the tariffs by explaining that they would help revive the United States' declining manufacturing industries; specifically, the steel industry. In 1953, after a swell resulting from the end of WWII, the U.S. steel industry reached its peak year, employing over 650,000 workers (Metzgar, 2000). In 2017, only 140,000 of those jobs remained (McBride, 2018).

Following President Trump's announcement, many expressed disdain for the tariffs by citing the possibility of a trade war. Yet, Mark Glyptis, president of the United Steelworkers in Weirton, found the news to be hopeful, remarking that the government has not been strict enough in implementing similar policies over the last 40 years (Singer, 2018). His hope is remarkable, as Weirton is a city that has been hit hard by the economic downturn that followed the fall of the steel industry.

At one time in West Virginia's history, one of the largest steel producing companies in the country called the state home. In 1909, Ernest T. Weir bought 105 acres of land directly outside of Holliday's Cove, West Virginia, to expand his tin-plate company (Javersak, 1999). By relocating his steel production from Clarksburg to the shores of the Ohio River, Weir gained access to invaluable markets. Using his knowledge of the steel industry that he gained while working at U.S. Steel Corporation, Weir led his company to be the top employer in the state (Javersak, 1999). The company enjoyed profits and steady growth until it, along with the entirety of the United States steel industry, began to fall to the circumstances of globalization in the 1970s and 1980s. 
To this day, there remains a lack of media coverage on Weirton Steel, the steel industry in West Virginia, and deindustrialization. A rather new phenomenon, deindustrialization is the social and economic change that occurs as economies advance and leave behind industrial activity. Often, there is much media coverage of the effects of deindustrialization, such as poverty, drug abuse, and crime; however, the root cause of these problems is generally left unexplored. This project will aim to produce an episodic podcast that highlights the rise and fall of Weirton Steel. More specifically, the podcast will bring-forth the personal narratives birthed from deindustrialization to give the people of Weirton a medium to share their resilient and resolute stories. This project is important because these stories have remained largely undocumented in an audio format, let alone other forms of media. With 15 years now passed since Weirton Steel's bankruptcy, new narratives and identity formations have been developed as deindustrialization has set in. Thus, there remains an ever-surmounting need to bring light to the rich history of Weirton, West Virginia, and to document its current state and the people who inhabit it.

\section{Literature Review}

History tells us, like it or not, as goes the mill, so goes Weirton, in good times and bad.

- David Javersak, History of Weirton

\section{Historical Background of Weirton}

Kelly and Zoric (1994) present the man behind the growth of Weirton as they describe Ernest Tener Weir's rise from a clerical worker to a steel magnate. The authors discuss how Weir's innovative and bold managerial style led the company to greatness by driving for integration, keeping national unions out of the picture, and staying on top of the newest technological advances. While they do fail to portray any of Weir's faults, such as the time in 1919 when the company's private police forced more than 100 strikers to kneel and kiss the 
American flag (Sann, 2010), their paper provides a look into the strategic management that fostered a winning environment in the steel industry.

Long before E. T. Weir made his way to the Upper Ohio Valley, a small agricultural village with a congenial name, Holliday's Cove, sat nestled near the Ohio River, about 30 miles north of Wheeling, West Virginia. In his book, History of Weirton, Javersak (1999) writes about Weirton from the early beginnings at Holliday's Cove to the turn of the 21 st century. Along with his own account as a long-time resident, Javersak uses personal anecdotes from Weirton citizens to recount major influences on the town, such as the river flood of 1912, E. T. Weir's visions for his company, WWII, and the importance of the multitude of ethnic groups that flocked to the city. As Weirton Steel grew, the city grew along with it, and Javersak gives great attention to the social and economic expansion of the area. He also details the changing demographics of the city during the 80 s and 90 s as manufacturing jobs dwindled across the country. He cites multiple reasons for Weirton Steel's decline, such as automation, international steel imports, and a lack of demand for steel packaging. Ultimately, Javersak would almost predict Weirton Steel's bankruptcy, as he relates that between 1989 and 1998, employment fell 40 percent and its stock price dropped from about $\$ 15$ to only $\$ 1.56$ (1999).

Martin (2015) provides more detail in his book to the close connection between Weirton Steel and its workers. He highlights how the area's resistance to national unions fostered a unique, rural-industrial community that preserved social and gender norms of their rural past. Martin expounds on the local standard of "making do," which meant families emphasized selfreliance by gardening, raising livestock, hunting, and homebuilding. Since men were most likely acting as breadwinners by working in the mill, this furthered the gender divide, and women were 
more likely to spend their time in the home, as compared to women in urban locations at the time.

After decades of success, Weirton Steel fell victim to the consequences of globalization in the 1970s and 1980s; however, the company was able to save itself from complete closure. Lieber (1995) recalls that in 1982, National Steel, Weirton's parent company, announced that due to low profits, it would have to either close the mill completely, or continue operations on a much smaller scale. To prevent closure, Weirton Steel employees bought out the company in an ESOP (Employee Stock Ownership Plan), the largest of its kind in the United States. Lieber's book provides meticulous details on the key players and the early economic arrangements of the deal, spelling out the story as a lawyer would.

Goldstein (1983) presents a deeper dive into National Steel's motives during the transition to the ESOP in his article published in The Nation. He outlines how National Steel had been divesting itself of holdings in the steel industry for several years and failed to technologically advance its mills, basically setting up Weirton and the rest of its steel plants for failure. Goldstein explains how Lazard Freres \& Company, an investment and asset management firm hired by Weirton Steel's Joint Study Committee, had considerable oversight and control over the deal with National, allowing them to make key decisions, such as appointing their choice of CEO for the company. This contrasts with Lieber's account, which did not delve too deeply into the ulterior motives of any of the actors involved.

After serving on the Weirton Board of Directors for eleven years, Smith (2003) wrote a first-hand account of executive mismanagement, extreme overruns, and undisclosed transactions that he believed led the company to rubble. Smith also pairs his account with appendices that contain memorandums, letters, and financial statements that correspond with his narrative. 
Twenty years after his first article, Goldstein (2009) published another article that found that the main catalysts for Weirton Steel's failures were a lack of modernization as other countries invested in new steel making techniques and the impossible competition created by consolidation of companies during the onset of neoliberalism. His two articles, paired with Lieber and Smith's books, give a well-rounded look into the unique ESOP that allowed Weirton to continue much longer than many of its competitors, as well as reasons behind the company's eventual bankruptcy in 2003 .

In most accounts of Weirton, there is acknowledgement of how the citizens bound their identity to the company and steel itself. Rine (2010) used a grounded theory approach in his master's thesis to explore the community narrative that was disrupted after the fall of Weirton Steel. He surveyed a sample of past and present Weirton citizens from a Facebook group called “I AM FROM WEIRTON, WEST VIRGINIA," to better understand how current and former citizens viewed the town. He found that a community that had once held a collective identity revolving around the steel mill split itself into three new narratives: one that was pessimistic, one that had realized itself as a suburb of Pittsburgh, and one which was hopeful for a successful economic future.

\section{Deindustrialization and the Need for Narrative}

In their encapsulating essay on deindustrialization, Strangleman, Rhodes, and Linkon (2013) explore over 30 years of work to outline the various ways the topic has been studied. Due to the long-term nature of industrial decline, the authors note that early literature on the subject was forced to examine immediate impacts. This was a limiting factor to older studies as the social and economic implications of deindustrialization are better understood after multiple years. The authors emphasize how contemporary work that employs multi-disciplinary methods 
ranging from photography to landscape studies are efficient in capturing the narratives and memories from the people who have experienced the process of industrial decline. They argue that by examining memories, we can understand how people draw upon their past experiences to make assumptions about their current social and economic situations (2013).

Frisch (2003) presents one of the first reflections on how dialogue can be used to prevent academic literature regarding public history from becoming so theoretically complex that it then becomes disconnected from the communities and people under study. Rather than relying only on expert opinions, one should integrate the voices of those who lived through a certain phenomenon, such as deindustrialization, thus presenting a more whole understanding of the concept. Calling for "dialogic sensibility," Frisch wishes for working-class studies to include multiple levels of experiences to give economically disadvantaged groups a seat at the table when discussing political matters that will directly affect them.

Uprichard and Byrne (2006) assert the need for narrative with their article that examines how stories of a person's lived experience are necessary to further triangulate studies that look at complex urban spaces. Specific to deindustrialization, there is an aspect of agency that is inherent within urban spaces, as they are both built and deconstructed by means of human interaction. Uprichard and Byrne (2006) suggest that studies of such work bring forth narrative to maintain the multidimensional aspects of the place under study.

\section{Media Projects on Industrial Decline}

Although not mentioned by Strangleman, Rhodes, and Linkon (2013), a film titled The Business of America by Adelman, Daressa, and Schmeichen (1984) is one example of an early representation of the immediate impacts of deindustrialization. The directors focus on the steel industry in western Pennsylvania, where U.S. Steel's Homestead plant fell victim to a lack of 
investment in new technology, rendering it uncompetitive with foreign mills that had been revolutionizing over the decades (1984). The interviews presented in the film expound on narratives of anger and disbelief offered by the Homestead workers as their corporate counterparts abandoned them. The documentary falls in line with Strangleman, Rhodes, and Linkon's (2013) observation that most work on deindustrialization is presented through the lens of place. And, with its narrative portrayals, it adds to a body of work that requires dialogic narrative as an essential pathway to fully evaluating the human aspect to industrial decline.

Walley (2015), too, stresses the importance of authentic voices in community work through the use of transmedia. She writes that by using transmedia (a combination of multiple forms of media) in anthropologic research, an open dialogue is created between researcher and subject. This allows for a piece of work that is available to all types of classes, no matter one's education level or economic status. She cites that her project focusing on industrial decline and class in Southeast Chicago has been produced in three different mediums: a website, a book, and a documentary (2015). Feedback from Southeast Chicago citizens to the multiple facets of the project allowed Walley to fully recognize and appreciate how delivering a project in varying forms enables wider spread consumption of the work and specifically allows the people whose narratives it describes to access it.

Machover and Pozzo Di Borgo (1984) bring to life Weirton Steel's transition from a privately-owned company to a worker-owned ESOP in their feature-length documentary film, The Great Weirton Steal. The film ties together footage from meetings, interviews, and b-roll to dive deep into the struggles faced by workers during the two years that were required for National Steel and Weirton's management to strike a deal. It provides a first-hand look into how 
the rank and file were left in the dark on most aspects of the bargain and the general opinions held by workers at the time.

Jones' (2010) documentary film Changing Gears: End of an Era combines interviews of historians and union members to display how the closing of BorgWarner's automotive plant in Muncie, Indiana, impacted the town. At its highpoint in the 1950s, the plant provided jobs for more than 5,000 people, and it remained an essential workplace for the city until it closed its doors to the last 790 workers left in 2009. The documentary reflects the close ties of the local labor union to the plant and how union members continuously fought until the end to keep the lights on.

Marovich's (2015) Searching for Dream Street is an on-going photographic project that explores hard-hit steel towns in the river valleys surrounding Pittsburgh, Pennsylvania. Some photographs display pain and crumbling infrastructure while others show examples of economic recovery projects and pride. One town featured is Braddock, Pennsylvania, which is home to Andrew Carnegie's first steel mill, Edgar Thomson Steel Works. The city's population dropped from around 20,000 at its height to about 2,000 today, and Marovich's photos often reveal this emptiness by juxtaposing lively events with long-abandoned buildings. The project's website also includes a journal section where Marovich goes into greater detail on his experiences within the cities and the unique townspeople he has met along the way.

In respect to the communities under study, an article by Arnold (2015) asks that photographers and film-makers take heed of the product they present when capturing images of deindustrialization. She argues that too often, decay photographers, through their search for a certain death-like aesthetic, have been complicit in perpetuating a state of dystopia and decline, thus preventing awareness of grassroots movements or other attempts to move an area past its 
state of economic hardship. This can be countered by pairing film, audio, or photography work with the dialogic narratives that Frisch calls for and making sure to include the promising advancements of a town.

Bradley, Shewbridge, King, and Stefano (2014) produced Stories of Deindustrialized Baltimore, a five-part radio series created by students from the University of Maryland, Baltimore County. Each episode offers oral histories from retired workers of Sparrows Point Steel Mill, which was the largest steel mill in the world in the mid-20th century. By relying on the voices of the workers rather than voiceover, the listener navigates through reoccurring themes of struggles in the mill, like discrimination, hard labor, and sometimes death. But, the stories also emphasize themes of comradery, unity, and a shared identity from the mill.

Schaper's (2011) “A Steel Town Looks At Its Future, And Sees Rebirth” is an episode of NPR's hard times: a journey across america, a series that takes listeners across the United States to hear stories from citizens who are struggling to survive in the economy. This specific episode showcases Granite City, Illinois, a steel town that was hit hard when U.S. Steel's Granite City Works plant laid off almost all of its workers in 2009. The mill did eventually reopen and still provides the city with well-paying jobs; yet, residents recognize that their local economy needs to diversify in order to guarantee a hopeful future.

Todd, Board, and Collins (2017) created The Struggle to Stay, a multimedia storytelling project produced for West Virginia Public Broadcasting. Focusing on the economic crisis in the region, the project weaves audio, text, and photography to highlight the narratives of Appalachians as they grapple with the question: should I stay, or should I leave? One set of episodes follows Dave Hathaway, a 38-year-old who lost his job as a coal miner in Greene County, Pennsylvania, which is located directly west of West Virginia's Northern Panhandle. 
Coming from a multi-generational coal mining family, Hathaway's predicament presents a shared story across Appalachia; as industry leaves, should I leave my roots in pursuit of a better life?

Marudas (2016) produced "Clairton, Hometown Pride Still Alive in a Declining Steel Town,” an episode from WHYY's Grapple podcast, a series dedicated to highlighting real stories of those who have lived through economic advancements that have left their communities in distress. This episode offers voices from Clairton, Pennsylvania, a steel town on the Monongahela River. Residents provide insight into how booming the city used to be, what keeps people around today, and some historical anecdotes. Like other stories heard from cities facing a similar situation, residents call for a diversification of their economy.

\section{Podcasting}

A podcast is "a program (as of music or talk) made available in digital format for automatic download over the Internet" ("podcast," 2018). Unlike traditional radio broadcasts, users are able to access podcasts on their own time and schedule. This allows for a personalized media experience as listeners choose content based on their own interests. Podcasting emerged as a new audio media format in 2004 and has exploded in popularity since, with an estimated 67 million listeners in the United States in 2017 (Activate, n.d.).

Among other things, podcasting is an accessible and shareable medium for non-fiction storytelling. Lindgren (2016) relates in her journal article that a new genre of podcasting is emerging called "personal narrative journalism." An audio project of this genre contains two features: a reliance on lived experiences to break down complex societal issues and a genuine conversation between presenter and guest as they form a personal bond (2016). This genre intertwines objectivity and subjectivity to offer listeners a greater connection to the subject under 
discussion as they become personally invested in the stories heard through their speakers or headphones.

\section{Research Statement}

By tracing the rich history of Weirton, West Virginia and Weirton Steel, this project will weave narratives with historical facts to present the stories of citizens living through deindustrialization. A critical cultural approach will be taken to examine and describe the culture that is both diminished and created from the effects of industrial decline (Baker, 2015). Though studying deindustrialization through the eyes of steelworkers presents a specific, focused narrative, the effects of the phenomenon are shared throughout all of America's past and present industrial workers (Thompson, 2012). In West Virginia, coal miners have witnessed the same fall as their steel-working counterparts, as the state once offered work directly out of high school but now has a diminishing workforce and population (Lannom, 2017). Through podcasting, this project will allow unheard and unshared stories to be broadcasted, giving greater insight and reason to the consequences and hopes of a deindustrialized state. It will empower those who have felt betrayed by the economy and allow narratives to be shared in such a way that those with similar stories can find a common ground across work, class, and place. It also aims to add a new dimension of media coverage that goes beyond the usual commentary on the declining coal industry and the opioid epidemic in West Virginia. And, rather than only highlighting the hard times faced by the region, the project will also bring light to ongoing revitalization efforts. Therefore, this project will attempt to answer the following questions:

RQ1: How has deindustrialization affected the city of Weirton, West Virginia?

RQ2: Do the narratives that arise from Weirton's deindustrialization mirror those found in previous studies on the effects of industrial decline (i.e. addiction, negative health 
effects, gambling...)?

RQ3: In what ways have the people of Weirton transitioned beyond their reliance on the steel industry in pursuit of new opportunities?

\section{Methodology}

This project will utilize in-depth interviews to extract the real-life experiences of those who were directly involved with Weirton Steel. As Tuten (2015) writes, in-depth interviews allow for a better understanding of the ideas and emotions of the subject under study, therefore offering "a deeper picture of the phenomenon of interest" (pp. 293). This qualitative method will be used under the scope of oral history, which aims to collect the personal, lived narratives of people who have experienced a specific occurrence firsthand. By recording and sharing narratives, history can be told by those who may not normally be regarded as historians. As narratives are shared, empathy is thus fostered and realized. Hatcher (2015) explains how this emotional connection to another's lived experience allows a greater understanding for a situation, in such a way that "the past becomes real to us, something tangible that relates to our own experience" (pp. 287).

*The podcast will include approximately five episodes that examine different themes related to the deindustrialization of Weirton. Unanticipated themes may very well arise during the interviewing process and further research. The following is a set of themes to work off of:

a. The first episode could delve into the history of the company to give the audience an appreciation for just how large and impactful it was in its heyday. This awareness will allow listeners to grasp the gravity of the situation when the mill's activity began declining and the company's eventual bankruptcy. This episode should also highlight 
what residents think were the most important aspects to be remembered about Weirton Steel at its highest point and the lives they lived during this period.

b. Another area of exploration could be to expand on residents' understanding of deindustrialization and its causes. Who do they blame for the hardship inflicted upon the town once the industry collapsed? Do they see deindustrialization in local terms, such as placing blame on local officials and managers, or do they connect their pain to steel towns across the nation and condemn the federal government and globalization? This answer might be very different between the manager, who retired, and the worker, who lost their job when the plant closed.

c. An episode could also track how some families were able to recover and flourish after the industry's fall. This could be contrasted with the fact that other families were heavily burdened with loss and struggle after Weirton Steel's bankruptcy. This episode will offer insight into how one's class status played into how hard the aftershocks were felt in the search for new areas of employment.

d. One theme may revolve around the American Dream and if Weirtonians still have faith in themselves and their children to achieve it. For example, Weirton Steel was known as a family mill because it was multi-generational: a set of people from a family would work there, passing the trade down from one generation to the next. This chain was interrupted and the children whose parents were able to step directly out of high school into well-paying jobs with good benefits have to now enter society with a completely different worldview of what is needed to achieve success in today's economy. 
e. Another theme could focus on the identity transformation of Weirton citizens. As discussed in the literature review, Rine (2010) related that Weirton's community narrative that once depended on the steel mill has now been lost. So, where does identity come from if not work? And how do Weirtonians perceive themselves without the steel mill?

f. An additional episode can explore the women workers of Weirton Steel. How was their experience in the mill different than their male counterparts? Were they limited to certain roles and jobs? In what ways did gender-discrimination play out in Weirton Steel, and how did women overcome it?

g. Lastly, an episode will revolve around the future of Weirton. How has the area come to terms with industrial decline, and what are the next steps to be taken to advance the area? This episode will take a more optimistic route as it will showcase the new industries that have taken flight in the area and how citizens are contributing to push the city forward.

Based on these themes, the following is a list of intended interview participants:

1. a manager who retired, a worker who was laid off, someone who worked in the mill in the $50 \mathrm{~s}$ or $60 \mathrm{~s}$, a person who was a child in Weirton in the 50 s or 60s, members of the United Steelworkers union

2. a teenager or young adult that currently resides in Weirton

3. a person or a few individuals from a family that worked in the mill across multiple generations

4. women who worked in the mill as well as women whose husbands worked in the mill 
5. a person or family that has recently moved to Weirton for work unrelated to the steel industry, business owners, oil and gas workers, community leaders

The interview participants will be found by way of the researcher placing herself into the community under study and asking members as to who may offer the best narratives for the project (a list of prospective sources can be found in Appendix B). The researcher can begin their selection process at the Weirton Area Museum and Cultural Center. The museum, which is run by residents of Weirton, could be a potential starting point to finding subjects who will be willing to participate in the project. The researcher could ask the workers at the museum about their relationship to Weirton Steel. These workers will be able to provide their insights into possible interview subjects as they will have personal connections to people who have lived in Weirton for the entirety of their lives.

Interviewees will be screened and selected based on their affiliation with Weirton Steel and the consequences and/or benefits they experienced due to its bankruptcy. Participants will be asked about their personal experiences with the effects of deindustrialization, their understanding of how it has affected the world around them, and other related subjects. A sample interview guide and questions for participants who were lower-level workers in the mill can be found in Appendix A. Other interview guides or thematic outlines will be developed as specific interview participants are selected and episode topics are finalized. These interviews will be conducted in intimate locations, such as the participant's living space, so that the viewer can develop a better 'feel' of the subject's current situation. Portrait photographs will be taken of interview participants to be paired with the podcast on its publication site.

Interviews will be recorded with audio equipment. Natural sound and music will be paired with narrative to foster a greater connection between listener and participant. This podcast 
format will enable the final project to be shared with those who may not have access to academic journals in which a more traditional study would otherwise be published.

\section{Audience}

The podcast will be published on SoundCloud, an online distribution platform for audio projects. Those interested in listening will be driven to the final product by means of social media; a link and description will be shared on networking sites such as Twitter, Facebook, LinkedIn, etc. By publishing on an audio streaming site, the producer will give users the ability to listen and share as they please. This allows for easy, on-demand access, and the ability to reach a larger audience through the potential follower networks of those who choose to share the podcast.

The podcast will also be pitched to West Virginia Public Broadcasting (WVPB) a public media source. WVPB already hosts an array of projects dealing with topics similar to this podcast, such as Inside Appalachia, Us \& Them, and The Struggle to Stay. Further, WVPB has a wide-reaching audience that is concerned with deindustrialization and other economic and cultural phenomena regarding Appalachia. Thus, if this project is broadcasted and shared by WVPB, a large number of people already interested in or even affected by the rise and fall of Weirton Steel can be reached.

\section{Project Summary}

The above methodology was a preliminary list of potential themes, interview subjects, and directions to guide the work of the project. The following section seeks to guide the reader through the actual steps taken to complete the project and to describe the interviews and themes that grounded the final product. 


\section{Chronology}

The initial research and project development began during the spring semester of 2018 as a 'mock' proposal for JRL 520 Advanced Journalistic Writing/Research. This original proposal centered around creating a video documentary regarding the deindustrialization of Weirton, West Virginia. While providing a strong framework and literature review to work off of, this preliminary proposal lacked a detailed methodology and also needed a more refined focus and objective. At the beginning of the Fall 2018 semester, committee chair Mary Kay McFarland introduced the idea of reworking the project into a podcast, which made the overall timeline more feasible and emphasized a voice-driven personal narrative.

With the successful completion of the proposal defense in early December 2018, the next step that needed to be taken was to hit the ground and begin conducting interviews, which are described in the next section in chronological order. The final interviews were conducted in early May 2019. Following publication of the podcast on West Virginia Public Broadcasting's website (with text stories and photos paired with each episode) the project was mostly finished in June 2019 after 18 months, pending the project defense and final feedback in July 2019.

\section{Interviews}

i. $\quad$ John Bolzano - USW Local 2911 Benefits Coordinator, retired steelworker

In mid-January I spoke with John, who provided a detailed explanation of the steelmaking process as well as the major developments at Weirton Steel throughout its years.

ii. Charles Varano - Author of Forced Choices: Class, Community, and Worker Ownership 
Charles' book examines the paternalistic characteristics of Weirton Steel that were fostered by E. T. Weir and other top managers, and how this structure affected the Employee Stock Ownership Plan many years after Weir's death. Our conversation mainly dealt with his book and clarifying paternalism in Weirton.

iii. Mary Tice-Medical administration worker living in New Cumberland, W. Va.

Mary Tice's husband, Larry Tice, a Weirton steel employee of more than 30 years, tragically committed suicide following the mill's bankruptcy. Mary filled me in on her life with Larry and the circumstances that led to her husband's untimely death. This emotional interview brought forth the sometimes tragic social and emotional tolls felt by those in deindustrialized communities.

iv. Mark Glyptis - USW Local 2911 President, retired steelworker

After becoming disgruntled by the lack of pro-labor action being taken by the Independent Steelworkers Union at Weirton Steel, Mark put in his bid for union president in 1991. We discussed his opinion as to why the American steel industry struggled to compete on a national level and how this caused Weirton Steel's downfall.

v. $\quad$ Tracey Lester - USW Local 2911 Steward, long-time steel-mill clerk

My interview with Tracey touched on many subjects, ranging from her struggles with discrimination as a black woman in the mill to her opinions on the current state of the steel industry. She offered insight into the differences of workplace culture under Weirton Steel and the mill's new owner, Arcelor Mittal, as well as how the steel tariffs instated by President Trump have helped the mill today.

vi. Enzo Fracasso - Weirton city councilman, retired steelworker 
Much like within Mary Tice's interview, Enzo, who worked in the mill from 1973 to 2017, told me personal stories of the highlights and dangers in the mill, as well as the aftermath felt following the fall of the steel industry. He also talked about his work as a city councilman and his hopes for Weirton, which basically was for the city to return to the state of prosperity that he remembered as a child.

vii. Margaret Cowell - Virginia Tech professor, specializes in economic development Margaret, author of Dealing with Deindustrialization: Adaptive Resilience in Eight Midwestern Regions, gave me information about how deindustrialized areas recover, why some areas bounce-back quick than others, and better informed my questions for economic developers in the region as well the mayor.

viii. Melanie Donofe - Lifelong resident of Weirton, W. Va., Hancock County school teacher

Melanie has been teaching in the Hancock County school system for nearly 30 years. She articulated how the schools in the Northern Panhandle have grown smaller and lost funding following the decline of the mill. Additionally, Melanie explained that she could tell a difference in the culture of the students as their parents became less able to support them at home.

ix. Gerry Donofe-Lifelong resident of Weirton, W. Va.

During the interview with Melanie, Gerry, her mother, walked into the room and joined the conversation. Having lived in Weirton since the late 1930s, she has seen the area transition from a bustling mill town to another victim of the rust belt.

x. $\quad$ Harold Miller - Mayor of Weirton, W. Va., former steelworker 
Harold "Bubba" Miller welcomed me into his office to discuss the adversities faced by the city after losing its largest employer and financial supporter. He informed me of the special agreement Weirton Steel had with the city for paying municipal taxes and how this brought on a large blow to the city budget following the bankruptcy.

xi. Bus Terminal Patrons - Residents of the Ohio Valley

In downtown Weirton, across from one of the main gates to the mill, sits a small luncheonette and taxi stand called Weir Cove Taxi. Once a bus terminal for Greyhound, it's really only a shell of its former self. Yet, many interesting characters still hang out there, and for a few hours on a Friday afternoon, I joined in on the conversations inside to see how everyone felt about the state of Weirton. I spoke with drivers, cashiers, and customers, and all provided their own unique perspectives while touching on similar narratives, such as the opioid epidemic, a lack of good-paying jobs, and the blight tinging the city.

xii. Festival of Nations Attendees - Residents of Weirton, W. Va.

In mid-March, I headed to the Millsop Community Center in downtown Weirton for the Festival of Nations. With the original idea from committee member Glynis Board, my plan was to gather as many voices as possible explaining their hopes for Weirton and the Ohio Valley to be edited together in a StoryCorps style. The festival lasted several hours which afforded me time to talk to many people, young and old. These mini-interviews provided a larger set of opinions and emotions regarding deindustrialization and the future of the area.

xiii. Patrick Ford - Director of the Business Development Corporation of the Northern $\underline{\text { Panhandle }}$ 
Having been involved with economic development in the Northern Panhandle since 2009, I sought out an interview with Patrick to discuss his work and the direction his corporation hopes to take the region in. Located in Weirton, the Business Development Corporation (BDC) uses a regional economic development approach focused on Hancock and Brooke counties as well as adjacent counties in Pennsylvania and Ohio. Patrick and his team are working to revitalize five industries (energy, chemical, value-added metals, manufacturing, and healthcare) as well finalizing the plan to bring a petrochemical ethane cracker plant to Dilles Bottom, Ohio, which is across the river from Moundsville, W. Va. Patrick predicted that this could lead to nearly 20,000 new jobs being created in the area.

\section{xiv. Sean O'Leary - Senior Policy Analyst at the West Virginia Center on Budget and}

\section{Policy}

Following my interview with Patrick Ford, I decided to reach out to Sean to discuss his opinion regarding the economic recovery in the Northern Panhandle and the tactics being used by developers. He detailed that even though the unemployment rate was falling in the area, a quarter of jobs in Hancock County still only provided low wages, which was originally discovered in a report he co-authored titled "Understanding LowWage Work in West Virginia." Sean also questioned whether it was a good idea to use tax-payer dollars to revitalize industries, such as manufacturing, that offer much fewer jobs than in previous decades due to mechanization.

\section{xv. Robert Maxim - Senior Research Analyst in the Metropolitan Policy Program at}

\section{Brookings}

This past January, Brookings released a report detailing how automation and artificial intelligence will affect the United States' workforce. A vital discovery I made while 
looking through the data was that, according to Brookings, nearly a third of all jobs in the Weirton-Steubenville metro area are likely to be automated in the next thirty years. An important question I wanted to ask Robert, one of the co-authors, was how automation might affect job creation predictions, such as those made by Patrick Ford. He explained he did not know of any calculations that factor automation into their equation, which means that economic developers may not be correctly predicting the amount of jobs that new plants will bring to the area.

xvi. Beverly Reed - Ohio Valley resident concerned about ethane cracker plant, Sierra

\section{$\underline{\text { Club Intern }}$}

Since not all Ohio Valley residents are keen to the idea of bringing petrochemical plants to area, I reached out to the creators of the website "www.nocrackerplantov.com" which details the environmental costs that the ethane cracker plant may bring to the valley. They put me into contact with Beverly Reed, a resident of Bridgeport, $\mathrm{OH}$., which is about 30 miles south of Weirton on the Ohio River. After finishing her nursing degree at West Liberty University, she decided to put off her healthcare career to pursue environmental activism in the Ohio Valley. As we talked, she explained some of the reasons why the groups she is involved with are trying to stop the plant from being built, such as the pollution that will be emitted from the cracker plant, its reliance on natural gas 'fracking', and the fact that it will be producing plastic.

\section{Episodes}

The outlining, scripting, editing, and revising of each episode was done in an on-going process as interviews were completed and transcribed. Because the potential themes for each episode outlined in the methodology were merely a starting off point, I allowed the stories 
brought forth from the interviews to decide how each episode would be shaped. The section below will summarize the episodes and the themes selected for each.

Episode 1 - What Happened Here?

To introduce the podcast, I decided to fully embrace the personal narrative style and situate the listener within my own desires for starting the project. Out of sheer luck, right before a huge section of the mill was imploded in Weirton this past March, my father was interviewed by a local news outlet, and I was given permission to use his soundbite in my project. The anguish in his voice over the loss of the mill and what it used to provide juxtaposes perfectly with the story I tell of my experience growing up in downtrodden Weirton. The episode also clarifies the definition of deindustrialization and a few ways the phenomenon manifested in Weirton. I end the short introduction with the direction I aim to take the listener throughout the rest of the episodes, which was to humanize and personify deindustrialization by hearing the stories of those who live within its grasp.

\section{Episode $2-$ He Could See Everything Folding}

While reading through news articles about Weirton, I found an Associated Press story written in 2006 by Vicki Smith that described the decline of the city through the lens of a death of a local steelworker named Larry Tice. Her article centered around an interview with Mary Tice, Larry's wife. Realizing that Mary might be willing to share her story with me, I decided to get in touch with her. After searching on social media, I noticed my old teacher, Melanie Donofe, was a mutual friend with Mary on Facebook, and she gave me her number with Mary's permission. 
Living by herself with her dog, Mary welcomed me into her home for several hours as we went over the devastating details of her husband's suicide. Like many others, Larry, after thirty years of dedication to Weirton Steel, was left in limbo after the mill's bankruptcy in 2003. His pension was cut in half, and he wasn't sure whether or not he could find a job of similar pay and benefits if he took a buyout. He was also concerned that his thirty years smelting steel left him with a skillset not easily transferable to a new area of work. This led him back to the mill after a year of being laid-off, but he still had to learn a new job at the tin-mill because the old section he used to work at was closed by the new owners. Mary voiced that he may have also been bullied after returning to work due to his slower learning speed. With the weight of the world on his shoulders, Larry took his own life in 2006 when he was 51 years old.

As I pointed out above, deindustrialization has an inherently human component, as industry is both built up and dismantled by people. Prosperity that was brought about by labor and grit can, and often does, eventually lead to decline as economies are reworked and capital is moved across borders with no care for the working-class that sacrificed their lives to an industry. Larry Tice's life and death brings visibility to this notion, and Mary's raw interview brings voice to the issue.

\section{Episode 3 - As Goes the Mill...}

To fully explain how Weirton Steel found its roots in the Ohio Valley and trace its path from greatness to downfall, the third episode features both archival sounds and interviews to explore the city and the mill's intertwined history. As touched on in the literature review above, the episode goes back to 1909, when E. T. Weir first established his mill in the Holliday's Cove area. Then, it leaps through time and touches on major 
historical happenings in Weirton, such as its participation in the battle of production during WWII, the importance of women at the mill and the discrimination they faced, the worker buyout of the mill in the mid 1980s, and its eventual bankruptcy. This episode helps spread awareness about the huge production that used to exist in Weirton, which better grounds the listeners' understanding of what was lost in the city when the steel industry fell in America.

Episode 4-Where is God Today?

Going back to the present, this episode emphasizes the current state of Weirton based on interviews with my former schoolteacher as well as members of the community who were at the Weir Cove Taxi cabstand in downtown Weirton. First, the scene is established by going over a list of consequences usually felt in deindustrialized localities, such as population loss, drug abuse, and an increase in suicide. Then, facts about Weirton's decline are paired with anecdotes of those who have felt the impacts of these community problems. For example, I discussed how the opioid epidemic has crept into Hancock County, and then allowed Melanie Donofe to speak about how one of her students saved their mother's life by calling 911 when their mother overdosed. Each unique voice in this episode expresses a different way that deindustrialization can materialize in a community, offering a personal look into the lives of those who continue to push forward although so much around them has changed.

\section{Episode 5-Moving Forward}

To finalize the series, I wanted to end on an episode that takes a forward-looking stance on the city and the Upper Ohio Valley in general. After reestablishing how much the city depended on the mill with a few soundbites from Weirton's mayor, Harold 
Miller, I then dive into a discussion of revitalization efforts in the area. The main focus revolves around Patrick Ford's work with the Business Development Corporation and his efforts to finalize a plan to build an ethane cracker plant along the Ohio River in Dilles Bottom, Ohio, about 40 miles south of Weirton. Since the petrochemical industry is a hot topic in the area and is seen as the best bet for economic revitalization in the region, I decided to look further into its possible benefits (tens of thousands of new jobs) as well as some of its issues (automation inhibiting potential job creation and environmental impacts).

Lastly, the episode ends with a StoryCorps style collection of voices of Weirton citizens touching on their hopes for Weirton. From young to old, their soundbites express a variety of emotions about the city and different levels of faith in the area's ongoing revival.

\section{Publishing}

The podcast was published on West Virginia Public Broadcasting's website in early July. In addition to the audio pieces, the episodes also featured a web version as well as photos of each person heard throughout the series. With WVPB's motto being 'Telling West Virginia's Story,' this project was a perfect fit for their content style and audience. This site of publication allows for the series to be heard by a large amount of people interested in the struggles that face Weirton and Appalachia writ large.

\section{Discussion}

This section will return to the research questions posed in the initial project proposal and attempt to answer them based on reporting and interviews conducted during the duration of the project. 
RQ1: How has deindustrialization affected the city of Weirton, West Virginia?

Now at the latter end of the project, a better question to be asked might be how hasn't deindustrialization affected the city of Weirton, West Virginia? Industrial decline's effects are wide-sweeping, and based on the interviews conducted, the people of Weirton are very familiar with these changes.

\section{Population Loss}

Between 1960 and 2017, Weirton lost 32\% of its population, or nearly a third of its citizens, falling from 28,201 in 1960 to 19,081 in 2017 . With the fall of the steel mill, a mass exodus from the area occurred while people realized economic security in the city was a thing of the past. Melanie Donofe, the teacher I spoke with, contextualized this population loss by looking at the education system. Compared to her graduating class, the high school seniors in the area have far fewer peers than before. During our interview, she told me:

"Look at Brooke High School and Weir High School. I mean, my graduating class was 347. I mean, you're lucky if you got 347 in three classes now. I mean, last year they graduated less than 150 . So that, I mean that right there speaks volumes. There aren't any people here."

\section{Opioid Epidemic}

Weirton has also continued its battles with the opioid epidemic that is strangulating West Virginia. In 2002, only one Hancock County resident died from a drug overdose. The numbers have risen ever since. According to the West Virginia Health Statistics Center, between 2013 and 2017, the amount of drug overdose deaths a year in Hancock County per 100,000 residents was nearly three times more than the national average (2019). Melanie Donofe explained she had a very personal experience with the epidemic by telling me that:

"I've had a student this year that actually saved his mother's life. She overdosed and he called nine-one-one and they were able to give her Narcan and she was okay. So, I mean, as a 10-year-old, a 10-year-old shouldn't have to deal with that." 
Another person I spoke with, Chip Ray, a man who works at Weir Cove Taxi, related to me his view of the epidemic:

"It's a serious epidemic around here. I know a lot of people that were impacted by it, people that I know. People that I graduated with, people that I went to college with, a lot of, I can name 10 people that have died from opioids or heroin that I graduated with or who's close to my age. That's a shame. It's terrible. It's really impacting the area."

Job Insecurity and Low Wages

Hancock County's unemployment rate has fluctuated a lot over the last two decades.

After a low of $3.8 \%$ in 2001, it peaked at $13.7 \%$ in February 2010, following the Great

Recession. Thanks to economic revitalization efforts, the unemployment rate has reached a more manageable level as of late, coming to just under $6 \%$ this past January. Still, according to a report by the West Virginia Center on Budget and Policy, about one in every four jobs in Hancock County offers low-wages amounting to $\$ 1,250$ dollars a month or less (O’Leary, Wilson 2017). Ashley Shaffer, a worker at the Weir Cove Taxi stand, had this to say about employment in Weirton:

“So, when I was 23, I was working at William's Country Club up on Marland Heights. I mean, work was good then, and now it's just like you can't, I mean you can barely find a job."

When I was speaking with Melanie Donofe, she contextualized the unemployment in the region and low-paying jobs with the loss of the mill:

"But they were always there for us, and I think the community really got used to that, that they would do anything. You know, go ask Weirton Steel. Ask them for a donation. And then they'd flip you some money. You can't do that anymore. Basically, the benefit of them being here was there were jobs for our parents. And not minimum wage jobs. Good paying jobs."

\section{Suicide}


In 2014, there were 36.5 suicide deaths per 100,000 residents in Hancock County (West Virginia Vital Statistics, 2014). This is a staggering amount compared to the national rate of 13 suicide deaths per 100,000 residents the same year (Curtin S. C., Warner, M., Hedegaard, H. 2016). In addition to Larry Tice's death, other suicides were mentioned by the people I spoke with. Enzo Fracasso brought up an instance when a close friend and coworker at the mill randomly stopped by his house one day while Enzo was outside doing yardwork. He recalled the dialogue:

"He goes, 'it was good knowing you.' I said, 'what you talking about good knowing me? The hell you talking about? Good knowing me? I know you, and I'll know you tomorrow, too.'

He goes, 'it was fun working with you.' I said, 'okay, well I'll see you at work tomorrow.'

I didn't think nothing of it. He went home. I've talked to a few other guys that we worked with. They said he stopped, he stopped and saw them too, talked to them. And he went home that night and left a note, killed himself. I think that was job related cause he was like really stressed out. I know, I've known a lot of them. Probably more than I want to know. I can tell you that."

\section{Loss of Hope}

Immediately after Weirton Steel's bankruptcy, both Weirton citizens and mill workers alike were left with an unsure future. Although no sociological study has been conducted in Weirton to measure the level of hope that citizens have regarding their future, I was able to gather some anecdotal comments about this topic. Mary Tice, the surviving wife of Larry Tice, explained how the town's dependence on Weirton Steel left her husband completely helpless after the mill's downfall:

"I think that was part of Larry's desperation too, it's like, what am I going to do? I have done nothing. I went straight from high school into this. What do I have to fall back on? What can I do if I take the buyout?"

More than fifteen years later, the combination of population loss, the opioid epidemic, and job insecurity in the region have left some hopeless about Weirton's recovery. Dianna 
Calandros, a former dispatcher for Weir Cove Taxi, brought this culmination of feelings into perspective during our interview:

"I love Weirton. I mean, I really do. I love Weirton. It's just that when it, when the mill went down, it's like everything faded. It's like, you know, it'll never ever be like it was and that's, that's, that's sorrowful if you're from around here. It really hurts your heart."

I then asked her if she had any hopes for Weirton, and she replied:

"No, not at all. I'm 66 years old, what the hell can I hope for?"

RQ2: Do the narratives that arise from Weirton's deindustrialization mirror those found in previous studies on the effects of industrial decline (i.e. addiction, negative health effects, gambling...)?

The narratives of Weirton's struggle with industrial decline closely mirror the hardships felt in other areas, especially areas that have had little to no economic recovery. For example, a project cited in the literature review, Stories of Deindustrialized Baltimore (2014), brought forth voices speaking on the fall of the Sparrows Point Steel Mill and its surrounding communities. The interviewees in that project mentioned several symptoms of decline that also occurred in Weirton, such as loss of population, an increase in unemployment, loss of small businesses, and loss of healthcare and benefits.

Similarly, in Marovich's (2015) project, Searching for Dream Street, parallels can easily be drawn between the run-down mill towns surrounding Pittsburgh, Pennsylvania, and Weirton. In this case, the decaying landscapes and abandoned houses Marovich photographed could be interchanged with the deteriorating houses in Weirton. Due to population loss, houses in deindustrialized areas were left abandoned with no resources available to maintain upkeep. RQ3: In what ways have the people of Weirton transitioned beyond their reliance on the steel industry in pursuit of new opportunities? 
As highlighted in the fifth episode of the podcast, the most obvious efforts of economic revitalization in Weirton stem from the work of the Business Development Corporation of the Northern Panhandle. During my interview with the organization's executive director, Patrick Ford, I learned of the multiple ways they are attempting to stimulate the Northern Panhandle's economy. In 2009, the BDC used a \$200,000 grant provided by the U.S. Economic Development Administration to fund a development consultation by AECOM, a multinational engineering firm. The firm's study identified five industries that they recommended the BDC should work to recruit to the area, which were energy, chemical, value added metals, transportation logistics, and healthcare.

With the ongoing natural gas boom making waves in the area, energy and chemical are the two industries I decided to focus on in terms of moving past the steel industry. This is because billions of dollars of investment are potentially available to build ethane cracker plants (petrochemical) in the area that would rely completely on natural gas extraction (energy). Yet, as expounded on in the podcast, the threat of automation makes the job forecast for these industries (some estimate tens of thousands of jobs) not a likely scenario.

\section{Conclusion}

There was a lot of pain expressed by the community members I spoke to as they dealt with the fact that their home has gone through so much hardship. To watch where one has grown up since childhood slip into a downward spiral, never to return to its former glory of prosperity and pride, is traumatic indeed. Even though the stories told by Weirton citizens echo across the rust belt, it still has its own idiosyncrasies that deserve to be recorded and shared.

I also made very personal insights and conclusions over the course of this project. As heard in the first episode, my ties to Weirton over the last four years have been strained, and until 
starting this research, I had little care for the city. Yet, I've been personally transformed by the process of making this podcast, which largely had to do with meeting so many members of the Weirton community that I had never before tried to reach out to. Many people my age have either ignored or failed to learn about the city's past, which often turns into resentment and misunderstanding. Yet, by learning about the structural issues that cause deindustrialization and hearing the stories of those who have suffered the consequences involved, this resentment and misunderstanding can change. I learned a lot about myself by talking to these people, each explaining a different part of my home that I never fully understood growing up. Appreciation has been born from resentment, and I now have a much stronger drive to give back to my community and help its battle through industrial decline.

Although there are many fingers pointing at different reasons for Weirton's decline, it is true that no one person, corporation, or institution will ever be found accountable for the turmoil experienced. Thus, it is important to keep interviewing both key actors surrounding the issue of deindustrialization as well as those who live through its progression to better understand the world we occupy and better inform our future decisions as the phenomenon continues to advance.

\section{Limitations and Suggestions for Future Research}

A large limitation of this project was my distance from Weirton. Although I do have family in the area and a place to stay, due to in-person classes at school, I had to drive back and forth from Morgantown to Weirton (an hour and a half drive) on the weekends. I found that some of my best interviews were conducted purely by chance, such as when I dropped into the Weir Cove Taxi cabstand and started talking to patrons. If I had been able to stay in Weirton for longer than a weekend's time, I believe more voices could have been collected, which would have led to 
more intriguing and personal stories of deindustrialization. And, distance inhibits developing face to face relationships, thus making it harder to build a rapport with interview participants. Therefore, future researchers should plant themselves in the community for a longer period of time to work on relationship building within the community.

With this in mind, another limitation was that only a few scenes were captured wherein a social gathering was occurring. A suggestion to expand on this would be to attend more community events or spend time with smaller and more personal groups that gather on a regular basis. While planted in the community over a period of time, much like is done in ethnographies, more narratives will be brought to attention, creating a more diverse range of opinions regarding deindustrialization.

Additionally, there is still plenty to be reported on in Weirton, West Virginia. One such topic is the lives of women in steel mills. Largely restricted to sex-typed jobs, women at Weirton Steel mainly occupied clerical roles in the mill. The main non-clerical work that women performed was called tin-flopping, where they sorted and inspected tin sheets. In 1974, women at Weirton Steel gained access to other areas of work in the mill by help of a court-ordered affirmative action program (Martin, 2015). The stories of women in industrial spaces is an area of research with plenty of room for further study, and especially so at Weirton Steel.

Another suggestion is to look into the mill town experience of people of color. Tracey Lester-Locke, a black woman who has worked at the mill for 45 years, spoke to me about some of the discrimination she faced in the mill. She also talked about her mother, who was a tinflopper, and her fight for civil rights at Weirton Steel in the 1960s. The voices of those at Weirton Steel, and today at ArcelorMittal, who continue to face discrimination stemming from the country's ongoing attempt to solve the racial issues caused by its history of slavery and Jim 
Crow policies, have stories needed to be recorded and dispersed for all to hear. Overall, intersectional examinations of industrial spaces, such as those that explore the interplay of race, sex, class, etc., is a ripe area for storytelling. With the limited amount of journalistic coverage on these topics at Weirton Steel, more research and narrative gathering should be performed in this regard.

Finally, as made clear by Strangleman, Rhodes, and Linkon (2013) deindustrialization is a phenomenon that continues to develop overtime, thus making it easier to study as it evolves year by year. Although this project has created a good timestamp of how the area is today, this will continue to change year by year, decade by decade. Thus, a continued examination of how deindustrialization affects Weirton and how the people deal with its repercussions is always an option for future research. 
Note: Interviewing for stories is a fluid process with frequent follow up questions to clarify or to ask for examples. The list below is a starting point for a basic interview. 


\section{Appendix A}

\section{Interview Guide}

Interviewer: Hello! My name is Ella Jennings, and I am a graduate student at West Virginia University. In pursuance of my Master of Science in Journalism, I am creating a podcast highlighting Weirton Steel: what it once was, and what it is now. I lived in Weirton from ages 8 to 18, and I graduated from Weir High School. My father and grandfather both worked in the mill. While I did grow up here, I want to find more out about my town's past; more so, I want to hear the stories of the people who lived and experienced Weirton at its highest and at its lowest.

I would like to ask you questions about your understanding of deindustrialization's effects on Weirton, West Virginia, and the economic factors and implications of this phenomenon.

Answering these questions is completely voluntary. With your consent, your identity and parts of your interview will be featured in the podcast, which may be presented to the public. I will be recording the interview with an audio recorder. Your answers will be transcribed at a later time. At any time, you may stop the interview. The interview will likely take 60 to 90 minutes.

Do you have any questions?

Are you ready to begin?

For documentation purposes, I would like to confirm that I am interviewing on at (name, date, time).

\section{Interview Questions}

1. How are, or were, you connected to Weirton Steel?

2. What is, or was, your job at Weirton Steel? Can you describe what you did?

3. How did you come about working at Weirton Steel?

4. How long did you work at Weirton Steel?

5. Do you have any family who worked at the mill? If so, what did they do there?

Thank you. We will now move on to discussing life when the mill was functioning at a high capacity.

1. Describe your daily life as a worker at the steel mill.

2. What would you say morale was like at the steel mill during its height? Can you give me an example?

3. What was the city like when Weirton Steel employed several thousands of people?

4. What was your social life like during this time?

5. How would you describe Weirton Steel's connection to the city?

6. What was the best thing about the steel mill? The worst?

Great. Now we will talk about Weirton Steel's decline. 
1. When was the first time you remember being afraid of the mill closing?

a. How did that make you feel?

2. What do you think were the main factors leading to the decline of the mill?

3. How often did workers discuss a possible closure? Can you remember when?

I am going to ask a few questions about the ESOP (Employee Stock Ownership Plan).

1. What was your opinion of the ESOP?

2. What made the ESOP initially work?

3. Why do you believe the ESOP eventually failed?

4. What was the general worker opinion regarding the ESOP?

Let's move back to the steel mill's decline.

1. At what time did you realize that Weirton Steel was going bankrupt?

2. How did the mill going bankrupt personally affect you?

3. What do you think was the worst aspect of the mill declining?

4. Have you experienced, or heard of, any tragedies that resulted from job loss or the decline of the mill?

5. Do you believe that the mill going bankrupt affected West Virginia as a whole?

6. What do you think people thought about management at Weirton Steel?

7. What did people think about the federal government regarding the decline of the mill?

a. What about the state government?

8. Were there ever any clear explanations or answers given regarding the mill going bankrupt?

Finally, let's talk about Weirton today.

1. How has family life in Weirton changed since the mill's decline?

2. What is social life like in Weirton today?

3. What problems have you seen pop-up in Weirton that you would attribute to the decline of the steel mill? Any opportunities?

4. Do you, or others you know, ever reminisce about Weirton's past?

5. What do you think could help Weirton today?

6. What are your hopes for Weirton?

Thank you for your thoughtful answers. I appreciate the time you have given me today. Do you have anything else you would like to add before we end the interview?

If you think of something you'd like to share, please feel free to contact me.

Again, I want to thank you for your time and I wish you the best.

Demographics:

Name:

Gender: 
Age:

Level of education:

Current job: 


\section{Appendix B}

\section{List of Prospective Sources}

1. Eugene Misch - Former steelworker at Weirton Steel

2. Burt Jennings - Previous fireman at Weirton Steel

3. David Javersak - Retired history professor at West Liberty University

4. James Lieber - Lawyer from Pittsburgh, Pennsylvania

5. Phillip Smith - Former member of Weirton Steel's Board of Directors

6. Don Goldstein - Former economics professor at Allegheny College

7. Mark Glyptis - Current president of United Steelworkers in Weirton

8. Patrick Ford - Executive Director of the Business Development Corporation of the Northern Panhandle

9. Dennis Jones - Historian and Executive Director of Weirton Area Museum and Cultural Center

10. Thomas Zielinsky - Author and former Senior Director of Information Strategy at Weirton Steel

11. Harold "Bubba" Miller - Mayor of Weirton

12. Jane Kraina - Librarian, historian, and executive assistant at Weirton Area Museum and Cultural Center

13. Mary Zwierzchowski - Librarian, historian, and executive assistant at Weirton Area Museum and Cultural Center 


\section{Bibliography}

Activate. (n.d.). Number of podcast listeners in the United States from 2014 to 2021 (in millions). In Statista - The Statistics Portal. Retrieved October 10, 2018, from https://www.statista.com/statistics/786826/podcast-listeners-in-the-us/

Adelman, L., Daressa, L., Schmeichen, B. (Co-directors). (1984). The Business of America [Motion picture]. United States: California Newsreel.

Arnold, S. (2015). Urban Decay Photography and Film: Fetishism and the Apocalyptic Imagination. Journal of Urban History, 41(2). 326-339. doi:10.1177/0096144214563499

Baker, S. (2015). Cultural and Critical Studies. In Sloan, D., Zhou, S. (Eds.), Research Methods in Communication. ( $3^{\text {rd }}$ ed.) Northport, AL: Vision Press.

Bradley, S., Shewbridge, B., King, N., Stefano, M. (Producers). (2014, May 12). Stories of Deindustrialized Baltimore [Podcast]. Retrieved from https://soundcloud.com/newmedia-studio/sets/stories-of-deindustrialized-baltimore

Comer, H. (2006). Portrayals of Appalachia in America 's Major Metropolitan Newspapers (Master's thesis). Retrieved from ProQuest Dissertations \& Theses Global. (Accession No. 305327983).

Curtin S. C., Warner, M., Hedegaard, H. (2016). Increase in suicide in the United States, 19992014. NCHS data brief, no 241. Hyattsville, MD: National Center for Health Statistics.

Frisch, M. (2003). Working-Class Public History in the Context of Deindustrialization: Dilemmas of Authority and the Possibilities of Dialogue. Labour/Le Travail, 51.153-64.

Goldstein, D. (2009). Weirton Revisited: Finance, the Working Class, and Rustbelt Steel Restructuring. Review of Radical Political Economics, 41(3). 352-357. doi:10.1177/0486613409336349 
Goldstein, D. (1983, December 10). The Weirton Buyout: Saving Jobs, But at What Price? The Nation. 594-597.

Hatcher, A. (2015). Oral History. In Sloan, D., Zhou, S. (Eds.), Research Methods in Communication. ( $3^{\text {rd }}$ ed.) Northport, AL: Vision Press.

Javersak, D. (1999). History of Weirton, West Virginia. Virginia: Donning.

Jones, J. (Director, Producer). (2010). Changing Gears: End of an Era [Motion picture]. United States: Ball State University's Center for Middletown Studies in conjunction with the Institute for Digital Entertainment and Education.

Kelly, E., Zoric, J. (1994). Lone Wolf at Weirton: Ernest Tener Weir. Journal of Managerial Issues, 6(4). 444-456.

Lannom, A. (2017, December 22). West Virginia among eight states losing population. The Register Herald. Retrieved from http://www.register-herald.com/news/west-virginiaamong-eight-states-losing-population/article_11ff80c0-20f9-5dc3-8ce68af0f2131749.html

Lieber, J. B., (1995). Friendly Takeover: How an employee buyout saved a steel town. New York: Viking.

Lindgren, M. (2016). Personal narrative journalism and podcasting. International Studies in Broadcast \& Audio Media, 14, 23-41.

Machover, R. (Producer), \& Pozzo Di Borgo, C. (Director). (1984). The Great Weirton Steal [Motion Picture]. United States: First Run Features

Marovich, P. (2015). Searching for Dream Street. Retrieved October 9, 2018, from http://searchingfordreamstreet.org/ 
Martin, L. (2015). Work and Identity in the Factory and at Home. Smokestacks in the Hills: Rural-Industrial Workers in West Virginia (pp. 125-154). Champaign, IL: University of Illinois Press.

Marudas, S. (Producer). (2016) Episode 07: Clairton, Hometown Pride Still Alive in a Declining Steel Town. Grapple [Audio podcast]. Retrieved from https://grapplepodcast.atavist.com/clairton

McBride, J. (2018, March 8). The Risks of U.S. Steel and Aluminum Tariffs. Council on Foreign Relations. Retrieved from https://www.cfr.org/backgrounder/risks-us-steel-andaluminum-tariffs

Metzgar, J. (2000). Striking Steel: solidarity remembered. Philadelphia, PA: Temple University Press

O’Leary, S., Wilson, R. (2017) 2017 State of Working West Virginia: Understanding Low-Wage Work in West Virginia. West Virginia Center on Budget \& Policy.

Podcast. 2018. In Merriam-Webster.com. Retrieved October 10, 2018, from https://www.merriam-webster.com/dictionary/podcast

Rine, J. (2010). The Once and Future Steel Town: The Narrative Identities of a Local Community (Master's thesis). Retrieved from ProQuest Dissertations \& Theses Global. (Accession No. 749230493).

Sann, P. (2010). The Lawless Decade: Bullets, Broads and Bathtub Gin (Green ed. edition). Mineola, N.Y: Dover Publications.

Schaper, D. (2011, November 30). A Steel Town Looks At Its Future, And Sees Rebirth. hard times: a journey across america [Radio broadcast episode]. Retrieved from 
https://www.npr.org/2011/11/30/142914799/a-steel-town-looks-at-its-future-and-seesrebirth

Singer, D. (2018, March 1). New tariff on foreign steel leaves mixed opinions. WTOV9. Retrieved from http://wtov9.com/news/local/new-tariff-on-foreign-steel-leaves-mixedopinions

Smith, P. H. (2003). Board Betrayal: Failed Governance and Management Hand in Hand with Arthur Andersen: An ESOP Fable. Pennsylvania: Ladlesheet Press.

Strangleman, T., Rhodes, J., Linkon, S. (2013). Introduction to Crumbling Cultures:

Deindustrialization, Class, and Memory. International Labor and Working-Class History, 84. 7-22. doi:10.1017/S0147547913000227

Thompson, D. (2012). Where Did All the Workers Go? 60 Years of Economic Change in 1 Graph. The Atlantic. Retrieved from https://www.theatlantic.com/business/archive/2012/01/where-did-all-the-workers-go-60years-of-economic-change-in-1-graph/252018/

Todd, R., Board, G., Collins, C. (2017). The Struggle to Stay [Audio series]. Retrieved from http://www.wvpublic.org/term/struggle-stay\#stream/0

Tuten, T. (2015). Oral History. In Sloan, D., Zhou, S. (Eds.), Research Methods in Communication. ( $3^{\text {rd }}$ ed.) Northport, AL: Vision Press.

Uprichard, E., Byrne, D. (2006). Representing complex places: a narrative approach. Environment and Planning A, 38. 665-676. doi:10.1068/a37333

Walley, C. J. (2015). Transmedia as experimental ethnography: The Exit Zero Project, deindustrialization, and the politics of nostalgia. American Ethnologist, 42(4). 624-639. doi:10.1111/amet.12160 
West Virginia Health Statistics Center (2019) Vital Statistics System, Drug Overdose Database. West Virginia Vital Statistics (2014) West Virginia Department of Health and Human Resources, Bureau for Public Health, Health Statistics Center. 